\title{
Disappearance Of The Natural Emergent 3-Dimensional Oyster Reef System Of The James River, Virginia, 1871-1948
}

\author{
H Woods
}

WJ Hargis Jr.

Carl Hershner

Virginia Institute of Marine Science, carl@vims.edu

Pamela Mason

Virginia Institute of Marine Science, mason@vims.edu

Follow this and additional works at: https://scholarworks.wm.edu/vimsarticles

Part of the Marine Biology Commons

\section{Recommended Citation}

Woods, H; Hargis, WJ Jr.; Hershner, Carl; and Mason, Pamela, "Disappearance Of The Natural Emergent 3-Dimensional Oyster Reef System Of The James River, Virginia, 1871-1948" (2005). VIMS Articles. 458. https://scholarworks.wm.edu/vimsarticles/458 


\title{
DISAPPEARANCE OF THE NATURAL EMERGENT 3-DIMENSIONAL OYSTER REEF SYSTEM OF THE JAMES RIVER, VIRGINIA, 1871-1948
}

\author{
HELEN WOODS, ${ }^{1, *}$ WILLIAM J. HARGIS JR., ${ }^{2}$ CARL H. HERSHNER ${ }^{2}$ AND PAM MASON ${ }^{2}$ \\ ${ }^{1}$ Patuxent Wildlife Research Center, Laurel, Maryland 20708; ${ }^{2}$ Virginia Institute of Marine Science, \\ Center for Coastal Resources Management Gloucester Point, Virginia 23062
}

\begin{abstract}
Anecdotal reports have long indicated that oysters, Crassostrea virginica (Gmelin), in the Chesapeake Bay once grew in large 3-dimensional reef structures. However, hard evidence of widespread 3-dimensional oyster reefs in the Chesapeake Bay has been scarce. This study uses data collected from historic charts of the James River, one of the most productive oyster producing tributaries of the Chesapeake Bay, to examine the natural occurrence of these reefs as well as their destruction. An early series of charts from the 1870s clearly documents widespread emergent oyster reefs in the James River from Burwell's Bay to Newport News Point. They were long, fairly wide, and shoal-like and oriented at right angles to the current. A 1940s series of charts indicates that by this time nearly all of these reefs had become submerged. Paired $t$-tests indicate a significant decrease in reef height and volume but not in reef area. This suggests that oysters and shell have been physically removed from the reefs. This likely had a major impact on water circulation patterns over and around the reefs, which may also have further adversely affected oyster populations.
\end{abstract}

KEY WORDS: oyster reef, Crassostrea virginica, Chesapeake Bay, James River

\section{INTRODUCTION}

The Chesapeake Bay, named Chesepiooc, the "great shellfish bay," by the Algonquin speaking Native Americans of the region, was once one of the most productive oyster (Crassostrea virginica) (Gmelin) producing estuaries in the world. With the advent of canning and the development of the railroad system, huge national and international markets were established for Chesapeake Bay oysters (United States Secretary of the Interior 1866,Wennerston 1981). From 1894 to 1912 annual oyster harvests in Virginia alone ranged from 5-7.5 million bushels (Hargis \& Haven 1988). Shells from the harvested oysters were not replaced on oyster grounds but removed and sold for a variety of commercial purposes ranging from road projects to chicken feed. This tremendous, largely unregulated harvest of oysters and shells wreaked havoc on the number of living oysters and their habitat (Wennerston 1981, Rothschild et al. 1994).

Throughout the 20th century, despite decades of overharvest and disease, the James River, a southern tributary of the Chesapeake Bay, has remained one of the most important and productive oyster areas in Virginia (Haven et al. 1978). This is mostly attributable to the water quality and hydrographic conditions of the river because circulation patterns in the Lower James trap and enhance residence time of oyster larvae in the river (Ruzecki \& Hargis 1989).

Oysters in the James River once grew on large reefs. Many of these reefs were 3-dimensional structures that breached the surface of the water at low tide (Marshall 1954) and provided habitat for a variety of organisms (Harding \& Mann 1999). The 3-dimensional structure of these reefs is believed to have favorably altered the environment for oysters by raising oysters off of the bottom into the upper water column. It is also believed that orientation coupled with the 3-dimensional reef structure increased water flow around the reefs, thereby decreasing sedimentation and increasing food availability (Grave 1905, Moore 1907, Masch \& Espey 1967, Lenihan 1999).

In the 19th and 20th centuries the James River reefs were heavily harvested, greatly altering the size and structure of the

*Corresponding author. E-mail: Helen_Woods@fws.gov reefs. This study documents the physical changes in the 3-dimensional oyster reef habitat of the James River from the 1870s to the 1940s. Historic hydrographic surveys were used to create and describe images of the bottom of the James River Estuary of 18711873 and 1940s. A series of paired $t$-tests were then performed to examine physical changes in the reefs.

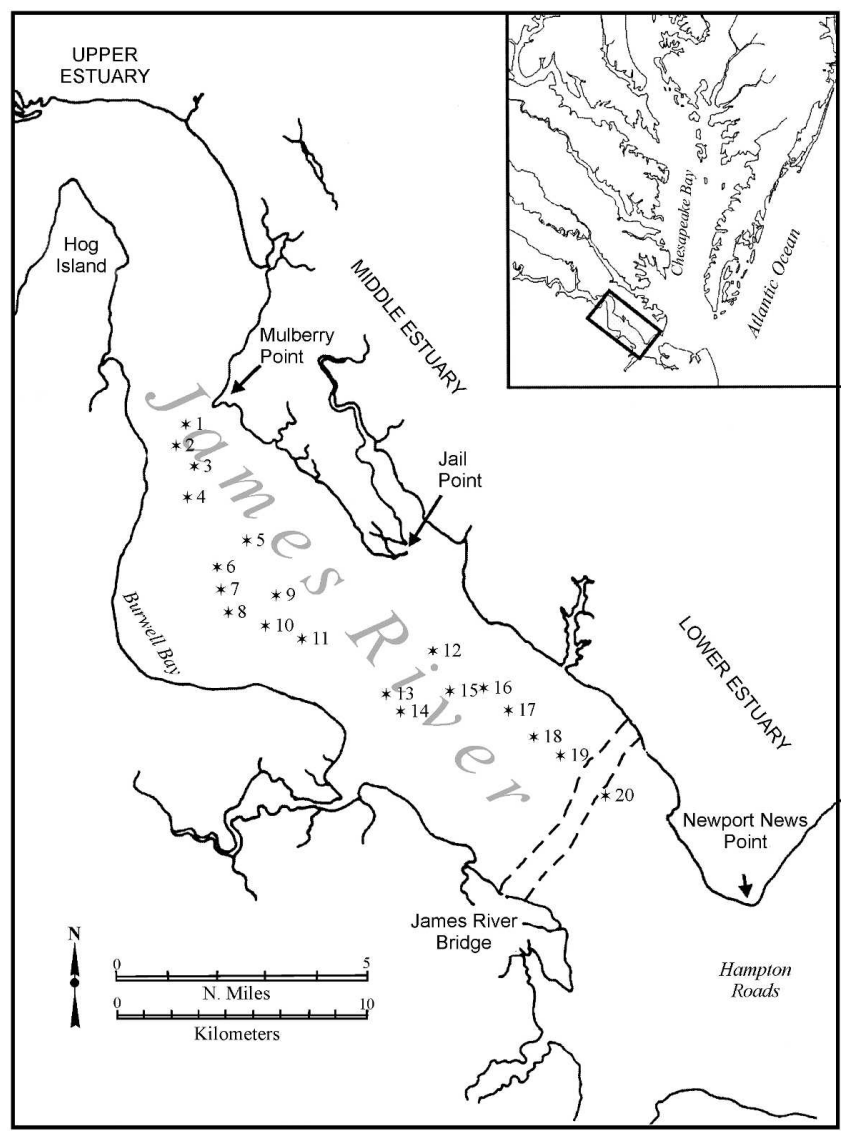

Figure 1. The James River estuary. Area in black represents some of the major reef systems. 


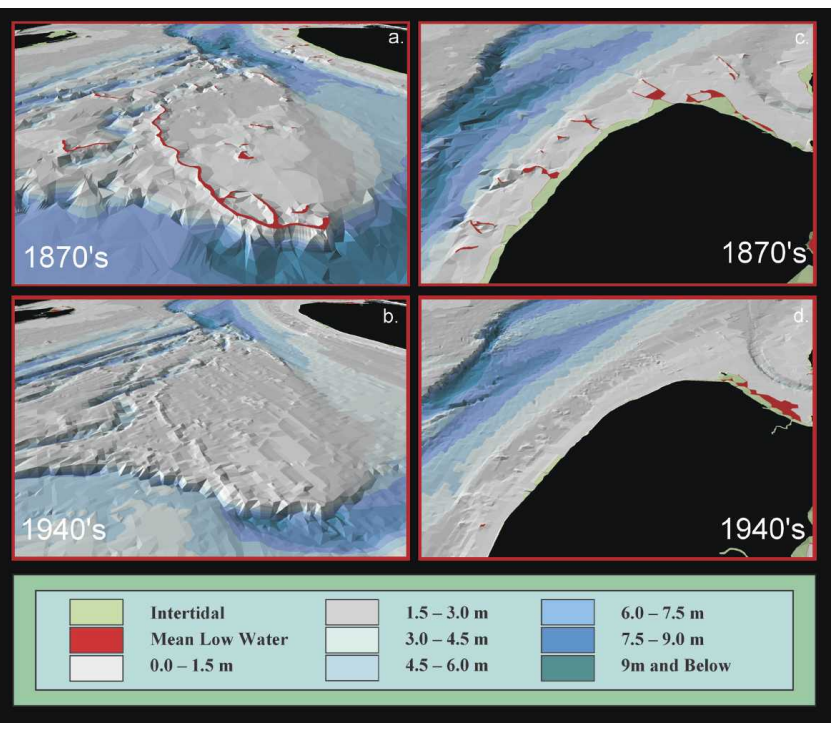

Figure 2. All figures vertically exaggerated by a factor of 10. A, Long Shoal Reef and surrounding oyster reefs in Burwell Bay, in the 1870s were large, emergent structures. B, By the 1940s, long Shoal Reef and the surrounding reefs had been severely reduced in height and broken into several segments. $C$, A series of evenly spaced reefs oriented perpendicular to the current along the outside bend of the river. D, By the 1940s these reefs had been severely degraded by over harvesting.

\section{STUDY LOCATION}

The James River is a partially-mixed estuary (Pritchard 1953, Nichols 1972) in southeastern Virginia. The study area is that portion of the James from Deep Water Shoals to Newport News Point (Fig. 1). Salinity ranges from 2-18.5 ppt in this area (Stroup \& Lynn 1963).

\section{MATERIALS AND METHODS}

Two detailed nineteenth century bathymetric charts and eight detailed twentieth century bathymetric charts of the James River between Hog Island and Newport News Point were used for computer analysis. US Coast Survey charts H01179a and H01179b were in paper format and depicted bathymetric soundings made from 1871 to 1873 , as well as the crests of many intertidal oyster reefs. US Coast Survey charts H06682, H06729, H07025, H07087, H07160, H0762, H07174, and H07641 were created during the period from 1941 to 1948 and existed in digital format.

The original 1870s charts were copied to Mylar and registered using ArcInfo, Geographic information system (GIS) software and a Numonics 2200 digitizing tablet. Approximately 30,000 depth soundings, coded to the nearest quarter foot, original shoreline, and mean low-water lines from the 1870 s charts were digitized to create GIS data layers. All depths were referenced to mean low water. These data were then translated into a 3-dimensional triangulated irregular network (TIN) model using the ArcView 3D Analist.

Digital data soundings of the 1940s charts were supplied by the Chesapeake Bay Program and were combined with a shoreline created from modern (1970s) USGS topographic maps. A TIN model was created using the ArcView 3D Analist in the same manner as the 1870s surveys. The depths of this TIN model were adjusted for sea-level rise by subtracting $0.29 \mathrm{~m}$ from each sounding. This is equal to 70 years of sea level rise (1927 to 1993) at the $4.20 \mathrm{~mm} / \mathrm{y}$ rate estimated by the National Ocean Service for the Hampton Roads tide station. A 2-m depth contour was then defined for this TIN model.

Visual inspection of the data with reference to oyster bottom data (Moore 1910, Haven \& Whitcomb 1983) indicated that the bases of many of the upthrusting oyster reefs in the study area were at a depth of $2 \mathrm{~m}$. Based on this information, a 2-m contour was

TABLE 1.

Reef change observed between 1870s and 1940s.

\begin{tabular}{|c|c|c|c|c|c|c|c|c|c|}
\hline \multirow[b]{2}{*}{ Reef } & \multicolumn{3}{|c|}{ 2D Footprint } & \multicolumn{3}{|c|}{ 3D Surface Area } & \multicolumn{3}{|c|}{ Volume } \\
\hline & $1870 s$ & 1940s & Change & $1870 s$ & $1940 s$ & Change & $1870 s$ & 1940s & Change \\
\hline 1 & 41093 & 18394 & 55 & 41098 & 18413 & 55 & 17923 & 8723 & -9200 \\
\hline 2 & 14594 & 13315 & 9 & 14631 & 13335 & 9 & 12640 & 9452 & -3187 \\
\hline 3 & 40840 & 72368 & -77 & 40850 & 72375 & -77 & 18950 & 29680 & 10730 \\
\hline 4 & 73476 & 64615 & 12 & 73490 & 64636 & 12 & 46874 & 38638 & -8236 \\
\hline 5 & 11521 & 41225 & -258 & 11524 & 41234 & -258 & 1887 & 17860 & 15973 \\
\hline 6 & 141922 & 142965 & -1 & 141938 & 142982 & -1 & 74938 & 59885 & -15053 \\
\hline 7 & 72318 & 42553 & 41 & 72344 & 42569 & 41 & 46819 & 26726 & -20093 \\
\hline 8 & 29841 & 8662 & 71 & 29858 & 8670 & 71 & 22420 & 3932 & -18488 \\
\hline 9 & 129672 & 10490 & 92 & 129775 & 10494 & 92 & 99696 & 3141 & -96555 \\
\hline 10 & 129672 & 94142 & 27 & 129775 & 94171 & 27 & 99696 & 50411 & -49286 \\
\hline 11 & 51963 & 36795 & 29 & 51976 & 36810 & 29 & 32043 & 20444 & -11599 \\
\hline 12 & 19629 & 53100 & -171 & 19633 & 53106 & -171 & 6528 & 21673 & 15145 \\
\hline 13 & 175605 & 161831 & 8 & 175671 & 161871 & 8 & 144779 & 113668 & -31111 \\
\hline 14 & 96657 & 93865 & 3 & 96716 & 93908 & 3 & 72887 & 60947 & -11939 \\
\hline 15 & 45111 & 35589 & 21 & 45131 & 35601 & 21 & 25266 & 17603 & -7663 \\
\hline 16 & 279115 & 246323 & 12 & 279135 & 246338 & 12 & 107960 & 89612 & -18348 \\
\hline 17 & 355282 & 285655 & 20 & 355364 & 285700 & 20 & 184992 & 136943 & -48049 \\
\hline 18 & 74105 & 90664 & -22 & 74128 & 90682 & -22 & 47629 & 43849 & -3780 \\
\hline 19 & 37231 & 64931 & -74 & 37239 & 64939 & -74 & 11944 & 22213 & 10269 \\
\hline 20 & 230509 & 321112 & -39 & 230572 & 321139 & -39 & 175734 & 116072 & -59662 \\
\hline
\end{tabular}


then created to define the outline or "footprint" of the reefs used for analysis in this study. Using the 1870s data, 20 upthrusting reefs were identified for comparison to the 1940s survey. Statistics for 2-dimensional surface area, volume, and maximum height were collected from the study reefs of both surveys. Paired $t$-tests were run on all of these parameters to compare the two data sets.

\section{RESULTS}

The surveys of the James River made in the 1870s show more than 2 dozen emergent oyster reefs from Burwell's Bay to Newport News Point. The 1940s surveys indicate that nearly all of the oyster reefs that were emergent in the James River in the 1870s had become completely submerged by the 1940s (Fig. 2). Only three small areas of reef remain emergent in these later surveys.

A significant decrease $(P>0.01)$ was found in the reef heights (Table 1, Table 2, Fig. 3). A significant decrease $(P>0.01)$ was also found between reef volumes in the 1870s and 1940s surveys. No significant difference was found between 1870s or 1940s surveys for 2-dimensional reef area (Table 1, Table 2).

\section{DISCUSSION}

This study provides quantitative evidence of the decline of the James River oyster reef system. We selected and examined 20 individual major upthrusting oyster reefs in the James River to provide a quantitative overview of the change in the reef system. We also incorporated some of the most recent estimations of sealevel rise rates to provide the greatest accuracy possible in quantitative reef calculations.

The data generated from the 1870 s surveys indicate that most of the upthrusting reefs are quite large, with the largest, Long Shoal Reef, stretching for $3 \mathrm{~km}$ (Fig. 4 Mariners Museum of Virginia). Reef bases were relatively wide such that these reefs were shoal-like in their structure. The reefs were located in relatively shallow water with depths of the reef bases generally around $2 \mathrm{~m}$. Most upthrusting reefs were oriented perpendicularly to the main current flow.

By the 1940s only remnants of these reefs remained. The bases of the original reefs can still be discerned by their relief from the surrounding bottom however, the reefs have been reduced in height by an average of $0.47 \mathrm{~m}$. Large gaps can be seen in Long Shoal Reef where portions of the reef were entirely removed. On average, nearly 18,000 cubic meters of oyster and shell had been removed from each of the reefs studied. Because oysters on these natural reefs grew in formations and densities much different from those on present-day reefs, it is impossible to calculate the total number of animals that may have been removed from any given reef.

Changes in volume may be attributed to either active removal of animals and shell or the slumping of the reef from the redistribution of "worked" reef material. If the change in volume were the result of slumping, then there would be an expected widening of the dimensional area as indicated by base measurements. The

TABLE 2.

Statistics of reef change between 1870s and 1940s.

\begin{tabular}{lcccc}
\hline \hline & $\mathbf{1 8 7 0 s}$ & $\mathbf{1 9 4 0 s}$ & Difference & $\mathbf{P}$ \\
\hline 2D Area $\left(\mathrm{m}^{2}\right)$ & 102508 & 94930 & 7578 & 0.4390894 \\
Volume $\left(\mathrm{m}^{3}\right)$ & 62580 & 44574 & 18007 & 0.0091378 \\
Height $(\mathrm{m})$ & -0.29 & -0.76 & 0.47 & 0.0002479 \\
\hline
\end{tabular}

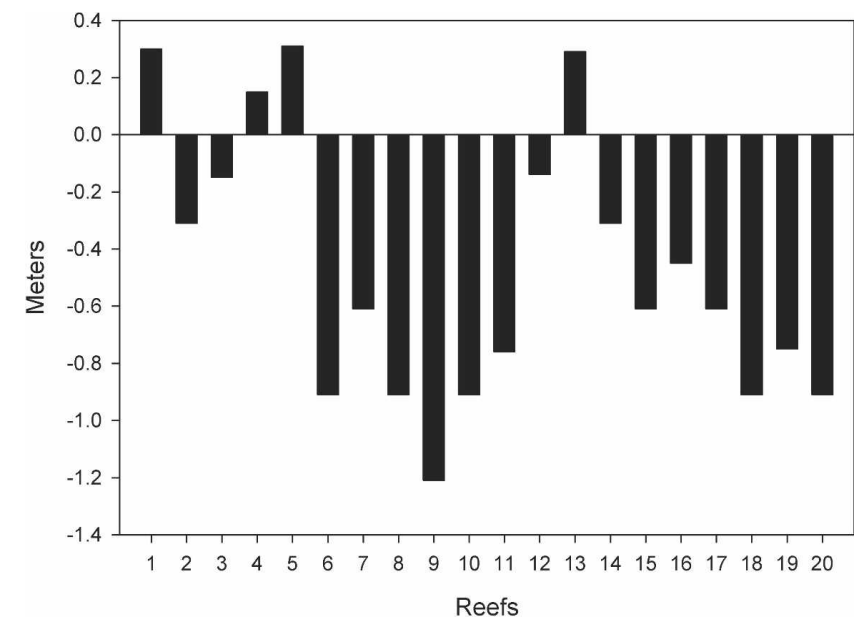

Figure 3. Change in reef height from 1870s to 1940s.

analysis does not show an increase in base width, thereby supporting the conclusion that change in reef volume from the 1870 s to the 1940s may be attributed to harvesting actions.

\section{ACKNOWLEDGMENTS}

The authors thank Rebecca Arenson and Elizabeth Mountz for the many hours they spent digitizing historic boat sheets. Julie Herman and Sharon Killeen provided considerable GIS assistance. David Evans assisted with statistical review. Dexter Haven provided the authors with insight from his many years of experience in this field. Marilyn Lewis and the VIMS library staff provided invaluable assistance in researching historic literature. Data were provided by the Chesapeake Bay Program and the National Ocean Service of NOAA. Funding was provided by the VIMS Center for Coastal Resources Management and the Virginia Sea Grant Program.

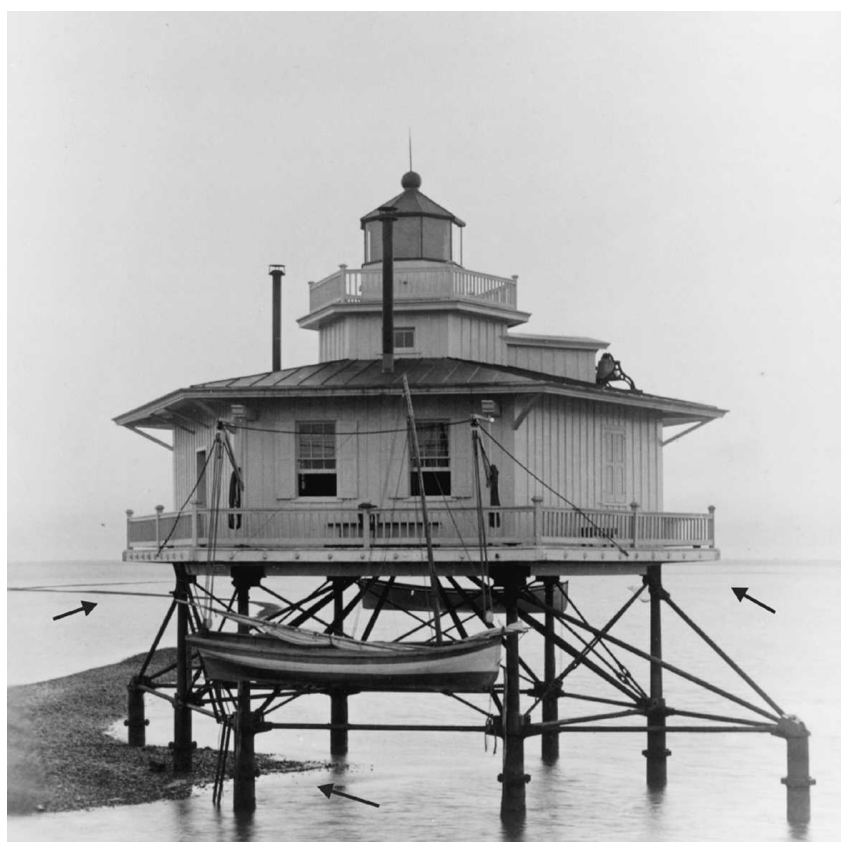

Figure 4. A lack of visible, large, craggy oysters in this photo of Long Shoal Reef suggests that this reef was suffering from over-harvesting by 1885. Photo courtesy of the Mariner's Museum of Virginia. 


\section{LITERATURE CITED}

Harding, J. M. \& R. Mann. 1999. Fish species richness in relation to restored oyster reefs, Piankatank River, Virginia. Bull. Mar. Sci. 65: 289-300.

Hargis, W. J., Jr. \& D. S. Haven. 1988. Rehabilitation of the troubled oyster industry of the lower Chesapeake Bay. J. Shellfish Res. 7:271-279.

Haven, D. S. \& J. P. Whitcomb. 1983. The origin and extent of oyster reefs in the James River Virginia. J. Shellfish Res. 3:141-151.

Haven, D. S., W. J. Hargis, Jr. \& P. C. Kendall. 1978. The oyster industry of Virginia: its status, problems and promise. VIMS special papers in marine science, vol. 5. Gloucester Point, VA: Virginia Institute of Science Sea Grant Program. 1024 pp.

Grave, C. 1905. Investigations for the promotion of the oyster industry of North Carolina. In: Report of the United States Fish Commission, 1903. Washington, DC: Government Printing Office. pp. 247-315.

Lenihan, H. S. 1999. Physical-biological coupling on oyster reefs: how habitat structure influences individual performance. Ecol. Monogr. 69: 251-275.

Marshall, N. 1954. Changes in the physiography of oyster bars in the James River, Virginia. The Virginia Journal of Science 5:173-181.

Masch, F. D. \& W. H. Espey. 1967. Shell dredging - a factor in sedimentation in Galveston Bay. Austin, TX: The University of Texas at Austin, Center for Research in Water Resources Technical Report HYD 06-6702 CRWR-7.

Moore, H. F. 1907. Survey of oyster bottoms in Matagorda Bay, Texas. US Bureau of Fisheries. Reference document No. 610. Washington, DC: Government Printing Office. 87 pp.
Moore, H. F. 1910. Condition and extent of the oyster beds of James River, Virginia. US Bureau of Fisheries. Reference document No. 729. Washington, DC: Government Printing Office. 86 pp.

Nichols, M. M. 1972. Effect of increasing depth on salinity in the James River estuary. In: B. W. Nelson, editor. Environmental framework of coastal plain estuaries. Memoir 133. Boulder, CO: The Geological Society of America. pp. 571-589

Pritchard, D. W. 1953. Distribution of oyster larvae in relation to hydrographic conditions. Proc. Gulf Carib. Fish. Inst. 5:123-132.

Rothschild, B. J., J. S. Ault \& M. Heral. 1994. Decline of the Chesapeake Bay oyster population: a century of habitat destruction and overfishing. Mar. Ecol. Prog. Ser. 111:29-39.

Ruzecki, E. P. \& W. J. Hargis. 1989. Interaction between circulation of the estuary of the James River and transport of oyster larvae. In: B. J. Neilson, J. Brubaker \& A. Y. Kuo, editors. Estuarine Circulation. Clifton, New Jersey: Humana Press. pp. 255-278.

Stroup, E. D. \& R. J. Lynn. 1963. Atlas of salinity and temperature distributions in Chesapeake Bay 1952 to 1961 and seasonal averages 1949 to 1961. Baltimore, MD: Chesapeake Bay Inst., John Hopkins Univ. Graph. Sum. Rep 2 (Ref. 63-1). 410 pp.

United States Secretary of the Interior. 1866. Statistics of the United States in 1860 of the eight census. Washington, DC: Government Printing Office. 539-542 pp.

Wennerston, J. R. 1981. The oyster wars of the Chesapeake Bay. Centerville, MD: Tidewater Publishers. $147 \mathrm{pp}$. 